\title{
A Scale for Measuring Sustainable Manufacturing Practices and Sustainability Performance: Validity and Reliability
}

DOI: 10.12776/QIP.V24I2.1385

\author{
Yousif M. Ibrahim, Norsiah Hami, Susan S. Abdulameer
}

Received: 2020-01-18 Accepted: 2020-03-24 Published: 2020-07-31

\begin{abstract}
Purpose: In quantitative studies, providing a valid and reliable instrument is necessary to ensure accurate results when measuring sustainable manufacturing practices (SMPs) and sustainability performance (SP). Therefore, this study aims to evaluate the validity and reliability of the measurements of SMPs and SP.
\end{abstract}

Methodology/Approach: The population of this study is top managers who have experience in the oil and gas industry (O\&GI) in Iraq. Two tests were carried out in the present study: the pre-test and the pilot test.

Findings: In the pre-test, the comments made by six academician experts and three practitioners were used to rephrase the measurements items and modify them according to the requirements of the O\&GI by the Iraqi context. Moreover, in the pilot test was all the items were reliable and were sufficiently correlated with their constructs.

Research Limitation/implication: There are some limitations to the current study. First, due to the small size of the study population, the pilot test sample in the current study was only 12 respondents. Future researchers can increase the sample size for the pilot test when they have a large population. Second, the validity and reliability of the measurements were tested in the current study in the oil and gas industry only. Future studies can test these measurements in other industries or small and Small and medium-sized enterprises (SMEs).

Originality/Value of paper: Theoretically, there are four contributions to the body of knowledge: first, introduce measures for SMPs according to the product life cycle view, it is limited in the literature. Second, these measures can be used by researchers to study the extent of SMPs and the SP of companies using descriptive statistics. Third, these measures can be used to investigate the impact of SMPs on SP by regression testing or structural equation modelling. Fourth, measures can be modified into open-ended questions for use in qualitative or 
mixed studies. Practically, there are two practical implications which explain in the conclusion.

Category: Research paper

Keywords: sustainable manufacturing practices; sustainability performance; pretest; pilot test; oil and gas industry

\section{INTRODUCTION}

Sustainability performance (SP) become an essential issue and a significant concern in the oil and gas industry (O\&GI) in Iraq (Ibrahim, Hami and Othman, 2019). This is because of the imbalance among the dimensions of SP that includes: economic, environmental and social sustainability. For example, the report of the ESCWA reported the proportion of Iraqi exports of oil equivalent to $99 \%$ of the total annual exports (UN-ESCWA, 2018). This establishes the importance of this industry in the economic development in Iraq. Nonetheless, this industry considers the main reason for environmental emissions and social damage (Elhuni and Ahmad, 2017).

Actually, due to their nature and size, the O\&GI has main impacts of health, safety global and environment (Schneider et al., 2011). Also, particulate matter and volatile compounds of filters in oil and gas companies cause many diseases, both for workers and the community in the same area, such as cancer diseases and respiratory diseases (EPA, 2003). Moreover, the main areas for the Extract and production of oil in Iraq, $70 \%$ of them have pollution matters in the environment and involve areas such as Kirkuk, Maysan, Basrah, Salah al-Din, Baghdad and Mosul (Al-Haleem, Awadh and Saeed, 2013). Nevertheless, to obtain a balance among the pillars of SP, there should be sustainable practices and activities in the O\&GI.

In this respect, empirical evidence in literature has confirmed that sustainable manufacturing practices (SMPs) according to the product life cycle view: sustainable product design (SPD), sustainable manufacturing process (SMP), sustainable supply chain management (SSCM) and sustainable end-of-life management (SEoLM) (Abdul-Rashid et al., 2017a), improve economic, environmental and social sustainability and thus balance it. To achieve this improvement and balance, there should be measurements valid and reliable regarding SMPs and SP.

According to Creswell and Creswell (2018), in quantitative studies, when there is any adapt on one or combine measurements, the prior validity and reliability may not apply for the new measurements. Hence, it has become significant to assessed new validity and reliability for the new measurements before conducting the main study. Therefore, this study aims to evaluate the validity and reliability of the measurements of SMPs and SP among the O\&GI in Iraq. The results of this study can be beneficial in several aspects. The researchers will 
have a valid and reliable instrument to measure SMPs and SP, particularly in the O\&GI. Besides, top management and managers in the O\&GI will obtain a deeper perception of how to measure SMPs and SP. Theoretically, there are four contributions to the body of knowledge: first, introduce measures for SMPs according to the product life cycle view, it is limited in the literature. Second, these measures can be used by researchers to study the extent of SMPs and the SP of companies using descriptive statistics. Third, these measures can be used to investigate the impact of SMPs on SP by regression testing or structural equation modelling. Fourth, measures can be modified into open-ended questions for use in qualitative or mixed studies. Practically, there are two practical implications. First, managers can measure their companies' implementation of SMPs using a 6-point Likert scale. Second, measure the level of SP achieved and compare with the performance in previous years.

\section{METHODOLOGY}

The O\&GI is one of the most top sectors that largely contributed to the GDP of Iraq (OPEC, 2018). This contribution is very important, especially in employment opportunities and exports. Consequently, the population of this study is top managers and senior executives who have experience in the O\&GI in Iraq. In parallel to the enormous contribution to the GDP of the country and its large contribution to the environmental and social impacts to the nation because its harmful operational activities. on the other side, the pre-test was conducted to verify the face validity (Hair et al., 2013). Then, the pilot test was carried out to establish the reliability of the measurements used in the current study (Saunders, Lewis and Thornhill, 2016).

Scaling design of the items will be used on a "6-point Likert scale": "1" = "Strongly Disagree" (SD); "2" = "Moderately Disagree" (MOD); "3" = "Slightly Disagree" (SLD); "4" = "Slightly Agree" (SLA); "5" = "Moderately Agree" $(\mathrm{MOA})$; and " $6 "=$ "Strongly Agree" (SA). The reason for using the 6-point Likert scale was to ensure that participants did not easily check the "indifference" option or "midpoint", as usually occur with a 5-point scale. The midpoint means the neutral response when answering the questionnaire with of exist an odd number of categories used in a scale (Hair et al., 2017). He also emphasised that the researcher usually uses the scale without the midpoint when many respondents are expected to choose neutrals on a particular issue. This is because it provides an easy option that needs a few efforts and is easily justified (Krosnick and Fabrigar, 1997). Garland (1991) argued that the participants would answer based on the content of the questions when given an even number of a response scale. Additionally, participants from Asian countries tend to choose the middle category response than those from Western countries ( $\mathrm{Si}$ and Cullen, 1998; Thrulogachantar and Zailani, 2011). It was also found that the validity and reliability of the findings tend to be higher for the even number response scale a six-point in particular (Chomeya, 2010) when compared to the odd number 
response scale (Krosnick and Fabrigar, 1997; Andrews, 1984; Alwin and Krosnick, 1991; Birkett, 1986; Coelho and Esteves, 2007).

The designed questionnaire was divided into three sections, which were the first section: focuses on SMPs implemented by oil and gas companies in Iraq, second section: focuses on identifying SP that can be achieved through the implementation of SMPs and the third section: provide a profile of the company and personal. Appendix (Table A1) states the items in the first and second sections of the questionnaire and the references adapted from them.

\section{RESULTS AND DISCUSSION}

\subsection{Pre-test (Validity)}

The pre-test process involves face validity. The face validity is done through systematic assessment of the measurement based on subjective judgment by the experts (Hair et al., 2013) to verify the measurement's ability to measure what it is supposed to measure in the study (Hair et al., 2017). They also pointed out that this validation method is commonly used in management and business research. Therefore, the study measurements that adapted from previous studies for the SMPs and SP were sent to six experts who are familiar with the constructs of this study to attest the face validity of the measurements. Additionally, three oil and gas industry's practitioners were also contacted for the same purpose. Their feedback, recommendations and comments have been made. Results of face validity by the experts in the pre-test is shown in Table 1.

Table 1 - Results of Face Validity by Experts in the Pre-Test

\begin{tabular}{|c|c|c|c|}
\hline Expert Type & Variable & Comment & Action \\
\hline Academicians & SMPs & $\begin{array}{l}\text { - Add the words "Our company } \\
\text { practices" at the below of each } \\
\text { dimension of sustainable manufacturing } \\
\text { practices. } \\
\text { - Modify the item by changing the word } \\
\text { "Eliminating" to "Eliminates" in the } \\
\text { item of "Eliminating the use of } \\
\text { hazardous materials during the design } \\
\text { of the products". } \\
\text { - Modify the item by changing the } \\
\text { worded "Design the products which } \\
\text { will prolong the life of materials". } \\
\text { - Modify the item by changing the words } \\
\text { "Savings of energy" to "Save energy" } \\
\text { in the item of "Savings of energy during } \\
\text { the manufacturing process". } \\
\text { - Modify the item by changing the word } \\
\text { "process" to "processes" in the item of } \\
\text { "Utilise lean production process". } \\
\text { - Modify the item by changing the word }\end{array}$ & $\begin{array}{l}\text { - "Our company practices". } \\
\text { - "Eliminates the use of } \\
\text { hazardous materials during } \\
\text { the design of the products". } \\
\text { - "Design the products } \\
\text { which will prolong its } \\
\text { lifetime". } \\
\text { - "Save energy during the } \\
\text { manufacturing process". } \\
\text { - "Utilise lean production } \\
\text { processes". } \\
\text { - "Adopts of sustainable }\end{array}$ \\
\hline
\end{tabular}




\begin{tabular}{|c|c|c|c|}
\hline Expert Type & Variable & Comment & Action \\
\hline & & $\begin{array}{l}\text { "Adoption" to "Adopts" in the item of } \\
\text { "Adoption of sustainable suppliers". } \\
\text { - Modify the item by changing the word } \\
\text { "Using" to "Use" in the item of "Using } \\
\text { a less, cleaner or reusable packaging". } \\
\text { - Modify the item by changing the } \\
\text { worded "Providing recycling support } \\
\text { using components and material coding } \\
\text { standards". }\end{array}$ & $\begin{array}{l}\text { suppliers". } \\
\text { • "Use a less, cleaner or } \\
\text { reusable packaging". } \\
\text { • "Provide recycling support } \\
\text { for materials and } \\
\text { components used". }\end{array}$ \\
\hline Academicians & SP & $\begin{array}{l}\text { - Summarising the existing statement } \\
\text { below the sustainability performance } \\
\text { then put it at the below of each } \\
\text { dimension of performance. } \\
\text { - Delete "s" from "emissions" and add } \\
\text { "es" to "gas" in the item "Reduced } \\
\text { emissions of greenhouse gas". } \\
\text { - Delete "s" from "wastes" in the item } \\
\text { "Reduced solid wastes". } \\
\text { - Delete "s" from "wastes" in the item } \\
\text { "Reduced liquid wastes". }\end{array}$ & $\begin{array}{l}\text { - "In the last three years, } \\
\text { please describe your } \\
\text { company's achievements } \\
\text { for economic performance } \\
\text { caused by the current } \\
\text { practices (as you described } \\
\text { in sections one and two)". } \\
\text { - "Reduced emission of } \\
\text { greenhouse gases". } \\
\text { - "Reduced solid waste". } \\
\text { - "Reduced liquid waste". }\end{array}$ \\
\hline Practitioners & $\begin{array}{l}\text { Profile of } \\
\text { company } \\
\text { and } \\
\text { personal }\end{array}$ & $\begin{array}{l}\text { - Change the options "Private/ local" and } \\
\text { "Private/ foreign" in the question "What } \\
\text { is ownership of your company?" in } \\
\text { section three to one option only as } \\
\text { "Private" and add one more option as } \\
\text { "Foreign". } \\
\text { - Add the options as "OHSAS 18001", } \\
\text { "ISO 29001" and "All" in the question } \\
\text { "Does your company have the } \\
\text { following certifications?" in section } \\
\text { three. } \\
\text { - Add the option as "General Manager" } \\
\text { and "Chief executive officer" in the } \\
\text { question "What is your current position } \\
\text { in your company?" in section three. }\end{array}$ & $\begin{array}{l}\text { - Done. } \\
\text { - Done. }\end{array}$ \\
\hline
\end{tabular}

\subsection{Pilot Test (Reliability)}

After the questionnaire is constructed (Sekaran and Bougie, 2016; Kumar, 2014), it is necessary to test it before using it to actual data collection (Dawson, 2009; Oppenheim, 2000; Adams, Khan and Raeside, 2014; Fink, 2017). This is because, without a trial test, we will not be able to tell if the questionnaire will succeed (Saunders, Lewis and Thornhill, 2016). Moreover, because this study adapted the measurements from different sources (Hair et al., 2014) regarding the constructs of SMPs and SP. 
Data collection in the research process usually begins with a pilot test (Cooper and Schindler, 2014). Saunders, Lewis and Thornhill (2009) defined a pilot test as "small-scale study to test a questionnaire, interview checklist or observation schedule, to minimise the likelihood of respondents having problems in answering the questions and of data recording problems as well as to allow some assessment of the questions' validity and the reliability of the data that will be collected".

There are many essential purposes for conducting the pilot test include understanding or interpreting questions by respondents (Kumar, 2011; Sekaran and Bougie, 2010) and clarity of wording of the questions and estimate achievement times (De Vaus, 2002; Adams, Khan and Raeside, 2014). Also, the pilot test will help to clarify the extent the flow and sequences of questions (Bryman and Bell, 2015; Oppenheim, 2000), as well as it will enable to get some evaluation of the validity of the questions and the potential reliability of the data to be collected (Saunders, Lewis and Thornhill, 2016). In order to achieve the purposes of the pilot test, Bell and Waters (2014) suggested to give the respondents a short questionnaire attached to the original questionnaire of the study includes a set of questions to know the following: (1) How long did it take to complete the questionnaire?, (2) were the questionnaire instructions clear?, (3) are there any unclear or vague questions? If there is, please specify, and why?, (4) do you have any objection to answering any question?, (5) do you think any significant topic has been deleted?, (6) do you think the layout of the questionnaire is clear/ attractive? and (7) any other comments?

Indeed, to make sure the questionnaire has achieved the purposes mentioned above (Oppenheim, 2000), the pilot test should be conducted with respondents who are similar to those that will be used in the full study (Saunders, Lewis and Thornhill, 2016; Zikmund et al., 2013; Hair et al., 2014). Naturally, the closer the link between the pilot sample and the final sample, the better (De Vaus, 2002). Given this, the reliability test must be carried out.

Principally, reliable measurements mean that they achieve the same result on repeated occasions (De Vaus, 2002). Cronbach's alpha was used for this purpose based on the recommendations of several researchers (e.g., DeVellis, 2016; Saunders, Lewis and Thornhill, 2016; Colton and Covert, 2007). Cronbach's alpha ranges from 0 to 1 , the lowest acceptance value 0.70 (Hair et al., 2013). Moreover, the item analysis method was used by corrected item-total correlation test to estimate the reliability of responses within an instrument (Colton and Covert, 2007; Field, 2009), as well as, explains the most correlated items with the construct, meanwhile the value of any item is less than .30 , it is deleted (Nunnally and Bernstein, 1994; Field, 2009; Hair et al., 2017). Bradburn, Sudman and Wansink (2004) recommended that no more than 10-12 participants are sufficient to detect the difficulties and weaknesses in the pilot test questionnaire. Likewise, Van Belle (2008) recommended that the sample size for the pilot test should be not a minimum of 12 participants. Besides, Fink (2013) stated that the minimum number of participants for a pilot test is 10 (cited in 
Saunders, Lewis and Thornhill, 2016). In short, the literature has illustrated that the sample of the pilot test is few and is not considered an issue either in quantitative or qualitative studies (Khattab and Wahid, 2015). Thus, 12 sets of questionnaires were distributed; all the questionnaires that were returned were usable. Using SPSS.V.25, the reliability of the measurements and the item analysis was analysed (Field, 2013; Pallant, 2011), as displayed in Appendix (Table A2).

Based on the pilot study feedback by the seven questions that attached to the original questionnaire of the study (Bell and Waters, 2014), certain words were reconstructed to provide a better understanding to respondents in the main survey. Also, the pilot test revealed that on average, respondents took about 15 to 20 minutes to complete the survey instrument. In addition, Table A2 (Appendix) shows that the result of reliability ranges from 0.794 to 0.906 suggested that all the Cronbach's alpha values were greater than 0.70 , which indicate that the 56 measurements were reliable (Hair et al., 2014). Besides, based on the item analysis, all the items correlate higher than 0.30 for the corrected item-total correlation, which ranged from 0.344 to 0.946 . These indicate that all items are correlated with their constructs. Therefore, all items have been retained without the need to delete any of them.

\section{CONCLUSION}

In conclusion, providing a valid and reliable instrument is necessary to ensure accurate results when measuring SMPs and SP. In this respect, two tests were carried out in the present study: the pre-test to establish the validity of the measurements, and the pilot test to check the reliability of the measurements. In the pre-test, the comments made by academician experts and practitioners were used to rephrase items and modify them according to the requirements of the O\&GI by the Iraqi environment. Moreover, in the pilot test, some significant findings were identified: an average, respondents took about 15 to 20 minutes to complete the questionnaire, the response rate was $100 \%$ high, all the items were reliable and were sufficiently correlated with their constructs. Therefore, this study provides valid and reliable measurements that can give a better understanding to researchers, top management and managers in the O\&GI on how to measure SMPs and SP. Theoretically, there are four contributions to the body of knowledge: first, introduce measures for SMPs according to the product life cycle view, it is limited in the literature. Second, these measures can be used by researchers to study the extent of SMPs and the SP of companies using descriptive statistics. Third, these measures can be used to investigate the impact of SMPs on SP by regression testing or structural equation modelling. Fourth, measures can be modified into open-ended questions for use in qualitative or mixed studies. Practically, there are two practical implications. First, managers can measure their companies' implementation of SMPs using a 6-point Likert 
scale. Second, measure the level of SP achieved and compare with the performance in previous years.

\section{REFERENCES}

Abdul-Rashid, S.H., Sakundarini, N., Ghazilla, R.A.R. and Ramayah, T., 2017a. Drivers for the adoption of sustainable manufacturing practices: A Malaysia perspective. Int. J. Precis. Eng. Manuf.-Green Tech., [e-journal] 18(11), pp.16191631. DOI: 10.1007/s12541-017-0191-4.

Abdul-Rashid, S.H., Sakundarini, N., Ghazilla, R.A.R. and Ramayah, T., 2017b. 'The impact of sustainable manufacturing practices on sustainability performance: Empirical evidence from Malaysia. International Journal of Operations \& Production Management, [e-journal] 37(2), pp.182-204. DOI: 10.1108/IJOPM-04-2015-0223.

Adams, J., Khan, H.T.A. and Raeside, R., 2014. Research Methods for Business and Social Science Students. 2nd ed. London: SAGE Publications.

Al-Haleem, A.A., Awadh, S.M. and Saeed, E.A.-J., 2013. Environmental Impact from Drilling and Production of oil Activities: Sources and Recommended Solutions. Iraqi Journal of Science, pp.46-53.

Alwin, D.F. and Krosnick, J.A., 1991. The Reliability of Survey Attitude Measurement: The Influence of Question and Respondent Attributes. Sociological Methods \& Research, [e-journal] 20(1), pp.139-181. DOI: 10.1177/0049124191020001005.

Andrews, F.M., 1984. Construct Validity and Error Components of Survey Measures: A Structural Modeling Approach. The Public Opinion Quarterly, [ejournal] 48(2), pp.409-442. DOI: 10.1086/268840.

Bansal, P., 2005. Evolving sustainably: a longitudinal study of corporate sustainable development. Strategic Management Journal, [e-journal] 26(3), pp.197-218. DOI: $10.1002 / \mathrm{smj} .441$.

Bell, J. and Waters, S., 2014. Doing Your Research Project: A Guide for FirstTime Researchers. 6th ed. Berkshire, UK: McGraw-Hill Education.

Birkett, N.J., 1986. Selecting the number of response categories for a Likert-type scale. In: N. Rothwell, XII. Cognitive Aspects Of Survey Methodology. Washington, D.C. pp.488-492.

Bradburn, N.M., Sudman, S. and Wansink, B., 2004. Asking Questions: The Definitive Guide to Questionnaire Design -- For Market Research, Political Polls, and Social and Health Questionnaires. 2nd ed. Hoboken, NJ: John Wiley \& Sons.

Bryman, A. and Bell, E., 2015. Business Research Methods. 4th ed. Oxford: Oxford University Press. 
Coelho, P.S. and Esteves, S.P., 2007. The Choice between a Five-point and a Ten-point Scale in the Framework of Customer Satisfaction Measurement. International Journal of Market Research, [e-journal] 49(3), pp.313-339. DOI: $10.1177 / 147078530704900305$.

Colton, D. and Covert, R.W., 2007. Designing and constructing instruments for social research and evaluation. San Francisco: John Wiley \& Sons.

Cooper, D. and Schindler, P., 2014. Business Research Methods. 12th ed. USA: McGraw-Hill Higher Education.

Creswell, J.W. and Creswell, J.D., 2018. Research Design: Qualitative, Quantitative, and Mixed Methods Approaches. 5th ed. USA: SAGE Publications.

Dawson, C., 2009. Introduction to Research Methods: A practical guide for anyone undertaking a research project. 4th ed. UK: Little, Brown Book Group.

De Vaus, D.A., 2002. Surveys in social research. 5th ed. New South Wales: Allen \& Unwin.

DeVellis, R.F., 2016. Scale development: Theory and applications. 4th ed. USA: SAGE Publications.

Elhuni, R.M. and Ahmad, M.M., 2017. Key Performance Indicators for Sustainable Production Evaluation in Oil and Gas Sector. Procedia Manufacturing, [e-journal] 11 (Supplement C), pp.718-724. DOI: 10.1016/j.promfg.2017.07.172.

EPA (Environmental Protection Agency), 2003. Environmental Impact of the Petroleum Industry. Environmental Update \#12, [onlien] June 2003. Available at:

$<$ https://cfpub.epa.gov/ncer_abstracts/index.cfm/fuseaction/display.files/fileID/1 4522> [Accessed 1 July 2020].

Field, A., 2009. Discovering Statistics Using IBM SPSS Statistics. 3rd ed. USA: SAGE Publications.

Field, A., 2013. Discovering Statistics Using IBM SPSS Statistics. 4th ed. USA: SAGE Publications.

Fink, A., 2013. How to Conduct Surveys: A Step-by-step Guide. 5th ed. USA: SAGE Publications.

Fink, A., 2017. How To Conduct Surveys: A Step-by-Step Guide. 6th ed. USA: SAGE Publications.

Frank, M.D., Nwuche, A.C. and Anyanwu, S.A.C., 2016. Operations management activities and organizational sustainability in oil and gas companies in rivers state. International Journal of Advanced Academic Research, 2(11), pp.34-56.

Garland, R., 1991. The mid-point on a rating scale: Is it desirable?. Marketing Bulletin, 2, pp.66-70. 
Hair, J.F., Black, W.C., Babin, B.J. and Anderson, R.E., 2014. Multivariate Data Analysis. 7th ed. USA: Pearson Education Limited.

Hair, J.F., Celsi, M., Money, A.H., Samouel, P. and Page, M.J., 2017. Essentials of business research methods. USA: Routledge.

Hair, J.F., Wolfinbarger, M., Bush, R.P. and Ortinau, D.J., 2013. Essentials of Marketing Research. 3rd ed. USA: McGraw-Hill Higher Education.

Chomeya, R., 2010. Quality of psychology test between Likert scale 5 and 6 points. Journal of Social Sciences, [e-journal] 6(3), pp.399-403. DOI: 10.3844/jssp.2010.399.403.

Ibrahim, Y.M., Hami, N. and Othman, S.N., 2019. Integrating sustainable maintenance into sustainable manufacturing practices and its relationship with sustainability performance: A conceptual framework. International Journal of Energy Economics and Policy, [e-journal] 9(4), pp.30-39. DOI: 10.32479/ijeep.7709.

Infante, C.E.D.., Mendonça, F.M.d., Purcidonio, P.M. and Valle, R., 2013. Triple bottom line analysis of oil and gas industry with multicriteria decision making. Journal of Cleaner Production, [e-journal] 52, pp.289-300. DOI: 10.1016/j.jclepro.2013.02.037.

Khattab, T.H. and Wahid, N.A., 2015. Penang User's Perception of Domestic Water Quality, Health Risk Concern and Willingness to Pay: A Pilot Study. Jurnal Teknologi, [e-journal] 74(11), pp.93-107. DOI: 10.11113/jt.v74.4878.

Krosnick, J.A. and Fabrigar, L.R., 1997. Designing Rating Scales for Effective Measurement in Surveys. Survey Measurement and Process Quality, pp.141-164.

Kumar, R., 2011. Research Methodology: A Step-by-Step Guide for Beginners. 3rd ed. USA: SAGE Publications.

Kumar, R., 2014. Research Methodology: A Step-by-Step Guide for Beginners. 4th ed. USA: SAGE Publications.

Nunnally, J.C. and Bernstein, I., 1994. Psychometric Theory. 3rd ed. New York: McGraw-Hill.

OPEC (Organization of the Petroleum Exporting Countries), 2018. Annual Statistical Bulletin. [pdf] Vienna: OPEC. Available at: $<$ http://www.thegulfintelligence.com/mediafiles/downloadfile/4833753a-f15946f2-8dc0-f2335344ebe6.pdf $>$ [Accessed 01 July 2020].

Oppenheim, A.N., 2000. Questionnaire Design, Interviewing and Attitude Measurement. USA: Bloomsbury Academic.

Pallant, J., 2011. Spss Survival Manual. 4th ed. New York: McGraw-Hill.

Paulraj, A., 2011. Understanding the relationships between internal resources and capabilities, sustainable supply management and organizational sustainability. Journal of Supply Chain Management, [e-journal] 47(1), pp.19-37. DOI: 10.1111/j.1745-493X.2010.03212.x. 
Saunders, M., Lewis, P. and Thornhill, A., 2009. Research Methods for Business Students. 5th ed. UK: Prentice-Hall.

Saunders, M., Lewis, P. and Thornhill, A., 2016. Research Methods for Business Students. 7th ed. UK: Pearson Education Limited.

Sekaran, U. and Bougie, R., 2010. Research Methods For Business: A Skill Building Approach. 5th ed. UK: Wiley \& Sons.

Sekaran, U. and Bougie, R., 2016. Research Methods For Business: A Skill Building Approach. 7th ed. UK: Wiley \& Sons.

Schneider, J., Vargo, C., Campbell, D. and Hall, R., 2011. An Analysis of Reported Sustainability-Related Efforts in the Petroleum Refining Industry. The Journal of Corporate Citizenship, 44, pp.69-84. DOI: 10.9774/GLEAF.4700.2011.wi.00006.

Si, S.X. and Cullen, J.B., 1998. Response Categories And Potential Cultural Bias: Effects Of An Explicit Middle Point In Cross-Cultural Surveys. The International Journal of Organizational Analysis, [e-journal] 6(3), pp.218-230. DOI: $10.1108 / \mathrm{eb028885.}$

Thrulogachantar, P. and Zailani, S., 2011. The influence of purchasing strategies on manufacturing performance: An empirical study in Malaysia. Journal of Manufacturing Technology Management, [e-journal] 22(5), pp.641-663. DOI: 10.1108/17410381111134482.

UN-ESCWA (United Nations Economic and Social Commission for Western Asia), 2018. External Trade Bulletin Of The Arab Region. [pdf] New York: United Nations. Available at: <https://www.unescwa.org/recurring-publicationidentifier/external-trade-bulletin-arab-region> [Accessed 01 July 2020].

Van Belle, G., 2008. Statistical Rules of Thumb. 2nd ed. UK: Wiley \& Sons.

Zhu, Q. and Sarkis, J., 2004. Relationships between operational practices and performance among early adopters of green supply chain management practices in Chinese manufacturing enterprises. Journal of Operations Management, [ejournal] 22(3), pp.265-289. DOI: 10.1016/j.jom.2004.01.005.

Zikmund, W.G., Babin, B.J., Carr, J.C. and Griffin, M., 2013. Business Research Methods. 9th ed. USA: Cengage Learning.

\section{ABOUT AUTHORS}

Yousif Munadhil Ibrahim - (Y.M.I.) Universiti Utara Malaysia, Malaysia, College of Business, School Of Technology Management \& Logistic, Dr., e-mail: yousifmonadhil58@gmail.com, Author's ORCID: 0000-0002-73142638. 
Norsiah Hami - (N.H.) Universiti Utara Malaysia, Malaysia, College of Business, School Of Technology Management \& Logistic, Senior Lecturer, e-mail: norsiahami@uum.edu.my, Author's ORCID: 0000-0002-9673-8012.

Susan Sabah Abdulameer - (S.S.A.) Universiti Utara Malaysia, Malaysia, College of Business, School Of Technology Management \& Logistic, Dr., e-mail: susansabah50@gmail.com, Author's ORCID: 0000-0003-4441-9930.

\section{AUTHOR CONTRIBUTIONS}

Y.M.I. - writing —original draft preparation; N.H. - supervision; N.H., S.S.A. review and editing.

\section{CONFLICTS OF INTEREST}

The authors declare no conflict of interest. The funders had no role in the design of the study; in the collection, analyses, or interpretation of data; in the writing of the manuscript, or in the decision to publish the results. 


\section{APPENDIX}

Table A1 - Measurement Items of SMPs and SP and Their References

\begin{tabular}{|c|c|c|}
\hline Code & Item & Reference \\
\hline \multicolumn{3}{|l|}{$S P D$} \\
\hline SPD.1 & $\begin{array}{l}\text { Eliminating the use of hazardous materials during the design of the } \\
\text { products. }\end{array}$ & \multirow{8}{*}{$\begin{array}{l}\text { Abdul-Rashid et al. } \\
(2017 a), \\
\text { Abdul-Rashid et al. } \\
(2017 b)\end{array}$} \\
\hline SPD. 2 & $\begin{array}{l}\text { Design the products which will facilitate disassembly of retired } \\
\text { products, separation of parts according to materials, as well as } \\
\text { reprocessing of materials. }\end{array}$ & \\
\hline SPD.3 & $\begin{array}{l}\text { Design the products which will facilitate repair, rework and } \\
\text { refurbishment. }\end{array}$ & \\
\hline SPD.4 & Design the products which will reduce material use. & \\
\hline SPD.5 & Design the products which will reduce energy consumption. & \\
\hline SPD.6 & Use environmental-friendly materials (e.g. recyclable materials). & \\
\hline SPD.7 & Design the products which support maintenance. & \\
\hline SPD.8 & Design the products which will prolong the life of materials. & \\
\hline \multicolumn{3}{|l|}{$S M P$} \\
\hline SMP.1 & Savings of energy during the manufacturing process. & \multirow{7}{*}{$\begin{array}{l}\text { Abdul-Rashid et al. } \\
(2017 \mathrm{a}) \text {, } \\
\text { Abdul-Rashid et al. } \\
(2017 \mathrm{~b})\end{array}$} \\
\hline SMP.2 & Emissions reduction during the manufacturing process. & \\
\hline SMP.3 & Improve manufacturing and machines efficiency. & \\
\hline SMP.4 & Utilise lean production process. & \\
\hline SMP.5 & Commitments to sustainable programmes, standards or regulations. & \\
\hline SMP.6 & Setting sustainable targets and objectives. & \\
\hline SMP.7 & Measure and inspection of material flows or wastes. & \\
\hline \multicolumn{3}{|l|}{$S S C M$} \\
\hline SSCM.1 & Adoption of sustainable suppliers. & \multirow{7}{*}{$\begin{array}{l}\text { Abdul-Rashid et al. } \\
(2017 a), \\
\text { Abdul-Rashid et al. } \\
(2017 b)\end{array}$} \\
\hline SSCM.2 & Influence suppliers to practice sustainable initiatives. & \\
\hline SSCM.3 & Sustainable collaboration with suppliers. & \\
\hline SSCM.4 & Impact customers to accept sustainable practices, services or products. & \\
\hline SSCM.5 & Using a less, cleaner or reusable packaging. & \\
\hline SSCM.6 & Use energy-efficient transportation. & \\
\hline SSCM.7 & Use energy-efficient logistics (e.g. warehouse location and routes). & \\
\hline \multicolumn{3}{|l|}{ SEOLM } \\
\hline SEoLM.1 & $\begin{array}{l}\text { Prolong the service life of products or materials by providing support } \\
\text { services to customers. }\end{array}$ & \multirow{3}{*}{$\begin{array}{l}\text { Abdul-Rashid et al. } \\
(2017 \mathrm{a}) \text {, } \\
\text { Abdul-Rashid et al. } \\
(2017 \mathrm{~b})\end{array}$} \\
\hline SEoLM.2 & $\begin{array}{l}\text { Providing hazardous waste treatment in the company for products } \\
\text { after recovery from the market. }\end{array}$ & \\
\hline SEoLM.3 & Providing and managing product warranty returns. & \\
\hline
\end{tabular}




\begin{tabular}{|c|c|c|}
\hline Code & Item & Reference \\
\hline SEoLM.4 & Providing and managing recalls (e.g. reconditioning, reselling). & \\
\hline SEoLM.5 & $\begin{array}{l}\text { Providing recycling support using components and material coding } \\
\text { standards. }\end{array}$ & \\
\hline \multicolumn{3}{|c|}{ Economic Sustainability } \\
\hline EcS.1 & Increased net profits. & \multirow{8}{*}{$\begin{array}{l}\text { Bansal (2005), } \\
\text { Paulraj (2011), } \\
\text { Elhuni and Ahmad } \\
\text { (2017), } \\
\text { Zhu and Sarkis } \\
\text { (2004) }\end{array}$} \\
\hline EcS.2 & Increased revenue growth. & \\
\hline EcS.3 & Increased revenue through the sale of waste products. & \\
\hline EcS.4 & Increased return on assets. & \\
\hline EcS.5 & Increased return on investment. & \\
\hline EcS.6 & Decreased costs. & \\
\hline EcS.7 & Commitment to production plan $\%$. & \\
\hline EcS.8 & Improving delivery performance. & \\
\hline \multicolumn{3}{|c|}{ Environmental Sustainability } \\
\hline EnS.1 & Reduced emissions of greenhouse gas. & \multirow{9}{*}{$\begin{array}{l}\text { Frank, Nwuche } \\
\text { and Anyanwu } \\
(2016), \\
\text { Paulraj (2011), } \\
\text { Zhu and Sarkis } \\
\text { (2004), } \\
\text { Elhuni and Ahmad } \\
\text { (2017) }\end{array}$} \\
\hline EnS.2 & Reduced flaring gas. & \\
\hline EnS.3 & Reduced solid wastes. & \\
\hline EnS.4 & Reduced liquid wastes. & \\
\hline EnS.5 & Reduced water usage. & \\
\hline EnS.6 & Reduced oil spills. & \\
\hline EnS.7 & Reduced energy consumption. & \\
\hline EnS.8 & Reduced consumption of hazardous/harmful/toxic materials. & \\
\hline EnS.9 & Reduced environmental accidents. & \\
\hline \multicolumn{3}{|c|}{ Social Sustainability } \\
\hline SoS.1 & Increased local procurement and supplier development. & \multirow{12}{*}{$\begin{array}{l}\text { Elhuni and Ahmad } \\
(2017), \\
\text { Frank, Nwuche } \\
\text { and Anyanwu } \\
(2016), \\
\text { Bansal (2005), } \\
\text { Infante et al. } \\
(2013)\end{array}$} \\
\hline SoS.2 & Increased preventing corruption. & \\
\hline SoS.3 & Increased workforce diversity. & \\
\hline SoS.4 & Increased workforce engagement. & \\
\hline SoS.5 & Increased workforce training and development. & \\
\hline SoS.6 & Decreased rates of work-related injury frequency. & \\
\hline SoS.7 & Decreased rates of work-related occupational illnesses. & \\
\hline SoS.8 & Decreased rates of work-related deaths. & \\
\hline SoS.9 & Participation in community affairs. & \\
\hline SoS.10 & Provide societal health facilities. & \\
\hline SoS.11 & Improved health and safety community. & \\
\hline SoS.12 & Increased social investment. & \\
\hline
\end{tabular}


Table A2 - Results of the Reliability Test in the Pilot Test

\begin{tabular}{|c|c|c|c|c|}
\hline Dimension & Item & \begin{tabular}{|l|} 
Corrected Item- \\
Total Correlation
\end{tabular} & $\begin{array}{l}\text { Cronbach's Alpha } \\
\text { if Item Deleted }\end{array}$ & Cronbach's Alpha \\
\hline \multicolumn{5}{|l|}{ SMPs } \\
\hline \multirow[t]{8}{*}{$S P D$} & SPD.1 & 0.796 & 0.884 & \multirow[t]{8}{*}{0.906} \\
\hline & SPD. 2 & 0.596 & 0.903 & \\
\hline & SPD. 3 & 0.818 & 0.882 & \\
\hline & SPD.4 & 0.532 & 0.907 & \\
\hline & SPD.5 & 0.727 & 0.893 & \\
\hline & SPD.6 & 0.818 & 0.882 & \\
\hline & SPD.7 & 0.652 & 0.898 & \\
\hline & SPD.8 & 0.670 & 0.896 & \\
\hline \multirow[t]{7}{*}{$S M P$} & SMP.1 & 0.613 & 0.877 & \multirow[t]{7}{*}{0.886} \\
\hline & SMP.2 & 0.406 & 0.903 & \\
\hline & SMP.3 & 0.661 & 0.872 & \\
\hline & SMP.4 & 0.744 & 0.861 & \\
\hline & SMP.5 & 0.848 & 0.848 & \\
\hline & SMP.6 & 0.744 & 0.861 & \\
\hline & SMP.7 & 0.753 & 0.860 & \\
\hline \multirow[t]{7}{*}{ SSCM } & SSCM.1 & 0.344 & 0.800 & \multirow[t]{7}{*}{0.794} \\
\hline & SSCM.2 & 0.726 & 0.728 & \\
\hline & SSCM.3 & 0.591 & 0.755 & \\
\hline & SSCM.4 & 0.434 & 0.784 & \\
\hline & SSCM.5 & 0.592 & 0.754 & \\
\hline & SSCM.6 & 0.592 & 0.754 & \\
\hline & SSCM.7 & 0.403 & 0.790 & \\
\hline \multirow[t]{5}{*}{ SEOLM } & SEoLM.1 & 0.836 & 0.853 & \multirow[t]{5}{*}{0.892} \\
\hline & SEoLM.2 & 0.927 & 0.823 & \\
\hline & SEoLM.3 & 0.775 & 0.861 & \\
\hline & SEoLM.4 & 0.685 & 0.882 & \\
\hline & SEoLM.5 & 0.531 & 0.908 & \\
\hline \multicolumn{5}{|l|}{$S P$} \\
\hline \multirow[t]{4}{*}{ Economic Sustainability } & EcS.1 & 0.819 & 0.880 & \multirow[t]{4}{*}{0.904} \\
\hline & EcS.2 & 0.665 & 0.895 & \\
\hline & EcS.3 & 0.730 & 0.888 & \\
\hline & EcS.4 & 0.741 & 0.889 & \\
\hline
\end{tabular}




\begin{tabular}{|c|c|c|c|c|}
\hline Dimension & Item & $\begin{array}{l}\text { Corrected Item- } \\
\text { Total Correlation }\end{array}$ & $\begin{array}{l}\text { Cronbach's Alpha } \\
\text { if Item Deleted }\end{array}$ & Cronbach's Alpha \\
\hline & EcS.5 & 0.946 & 0.868 & \\
\hline & EcS.6 & 0.574 & 0.902 & \\
\hline & EcS.7 & 0.639 & 0.897 & \\
\hline & EcS. 8 & 0.488 & 0.909 & \\
\hline \multirow{9}{*}{$\begin{array}{l}\text { Environmental } \\
\text { Sustainability }\end{array}$} & EnS.1 & 0.638 & 0.846 & \multirow[t]{9}{*}{0.864} \\
\hline & EnS.2 & 0.409 & 0.868 & \\
\hline & EnS.3 & 0.840 & 0.825 & \\
\hline & EnS.4 & 0.364 & 0.869 & \\
\hline & EnS.5 & 0.476 & 0.861 & \\
\hline & EnS.6 & 0.545 & 0.855 & \\
\hline & EnS.7 & 0.763 & 0.833 & \\
\hline & EnS.8 & 0.592 & 0.850 & \\
\hline & EnS.9 & 0.753 & 0.836 & \\
\hline \multirow[t]{12}{*}{ Social Sustainability } & SoS.1 & 0.847 & 0.879 & \multirow[t]{12}{*}{0.899} \\
\hline & SoS.2 & 0.517 & 0.896 & \\
\hline & SoS.3 & 0.579 & 0.893 & \\
\hline & SoS.4 & 0.528 & 0.895 & \\
\hline & SoS.5 & 0.596 & 0.892 & \\
\hline & SoS.6 & 0.800 & 0.881 & \\
\hline & SoS.7 & 0.402 & 0.902 & \\
\hline & SoS.8 & 0.860 & 0.878 & \\
\hline & SoS.9 & 0.600 & 0.892 & \\
\hline & SoS.10 & 0.501 & 0.897 & \\
\hline & SoS.11 & 0.477 & 0.898 & \\
\hline & SoS.12 & 0.774 & 0.885 & \\
\hline
\end{tabular}

(C) 2020 by the authors. Submitted for possible open access publication under the terms and conditions of the Creative Commons Attribution (CC-BY) license (http://creativecommons.org/licenses/by/4.0/). 